\section{Temperatures at the margins of a young spruce stand in relation to aboveground height}

\author{
Ondřej Špulák, Vratislav Balcar
}

Air temperature was monitored at a summit of the Jizerské hory Mountains (Czech Republic) in the vicinity of the northern and southern margins of a young Norway spruce stand (tree height approx. $4.5 \mathrm{~m}$ ) at 30, 60, 90 and 140 $\mathrm{cm}$ aboveground. Temperature sensors were placed at height intervals selected to represent terminal shoot heights in the planting stock of different treeheight categories (seedlings, semi-saplings and saplings). As reference, a point $30 \mathrm{~cm}$ aboveground in an adjacent treeless gap between stands was monitored. Measurements were taken in two periods, from April to October 2010 and 2011. Differences were evaluated in terms of mean temperature characteristics of the ground air layer in the stand gap and in each station at the stand margins. Differences in temperature extremes (minimum, maximum, range) values showed more conspicuous fluctuations than differences in mean values. The observed difference in the course of daily temperature in the ground air layer (up to $30 \mathrm{~cm}$ aboveground) between the stand gap and the southern margin of the spruce stand was small. The ground layer of air at the northern margin was markedly colder and showed a more stable course of temperatures. Decreasing temperature fluctuations were observed as distance from the ground increases, and frequency and intensity of ground frosts also decreased with sensors' height. At $140 \mathrm{~cm}$ aboveground (i.e., at approximately one-third of the spruce stand's height), differences between daily temperature characteristics at the southern and northern stand margins were small over the growing period, and the occurrence of late or early frosts showed comparable fre quencies. In conclusion, higher risk of damage to small-sized planting stock due to temperature stress was confirmed for higher mountain elevations. For the reconstitution of young coniferous stands, the choice of suitable planting sites within a small clear-cut area is relevant (in terms of temperatures near the terminal shoot) only when planting stocks of small dimensions are used.

Keywords: Air Temperature, Forest Stand Gaps, Mountains, Temperature Stress

\section{Introduction}

Location, size and shape of a clear-cut area (e.g., a gap or strip) determine the variability of microclimatic conditions for the subsequent regeneration of a forest stand (Krečmer 1982, Aussenac 2000, Langvall \& Löfvenius 2002, Spittlehouse et al. 2004). If a stand is to be regenerated, its influence on the environments of stand margins having different aspects (i.e., exposures) must be considered (Flemming 1987, Chen et al. 1993, Ritter et al. 2005). In cases when trees

are introduced into openings within young stands of preparatory or substitute tree species, the influence of the primary stand is expected to be limited by stand density, tree species composition, and size of the regenerated groups, as well as to increase with the stand growth (Göhre \& Lützke 1956).

The aspect of stand margins at gaps affects the penetration and intensity of solar radiation striking those margins (Otto 1994). Sunlight is a factor that markedly affects the thermal balance of the environment (Lang-

Forestry and Game Management Research Institute, Research Station at Opocno, Na Olive 550, 51773 Opocno (Czech Republic)

@ Ondřej Špulák (spulak@vulhmop.cz)

Received: Oct 10, 2012 - Accepted: Apr 19, 2013

Citation: Špulák O, Balcar V, 2013. Temperatures at the margins of a young spruce stand in relation to aboveground height. iForest 6: 302-309 [online 2013-07-16] URL:

http: / / www.sisef.it/iforest/contents/?id=ifor0815-006

Communicated by: Roberto Tognetti vall 2000). In spring, the potential for the growth of young plantations at mountainous sites is substantially influenced by the occurrence and intensity of ground frosts (Balcar \& Kacálek 2003, 2008, Uhlírová et al. 2004). To prevent frost damage to susceptible tree species, the selection of advanced planting material, including semi-saplings (common height: $51-120 \mathrm{~cm}$ ) and saplings (mostly over $120 \mathrm{~cm}$ in height - SchmidtVogt \& Gurth 1969, Huss 1993, Baláš et al. 2011), is frequently recommended.

As a consequence of dieback of forest stands due to air pollution in central European mountains and planting failure of native species, stands of substitute tree species mostly blue spruce (Picea pungens Engelm.) - were planted on large areas (Tesar 1982, Hering \& Irrgang 2005, Slodičák et al. 2005), while pure Norway spruce (Picea abies L.) stands were planted in more favourable conditions. Pollutant emissions were reduced during the 1990s (Fottová \& Skorepová 1998), and an effort to reintroduce native, more sensitive species into the above stands is currently undertaken. An essential part of stands proposed for conversion using substitute tree species is currently at the stage of young growth to small pole forest (Küßner \& Mosandl 2002, El Kateb et al. 2004, Slodičák et al. 2005, 2008).

For interplanting coniferous stands with seedlings (planting stock sized up to 50 or $70 \mathrm{~cm}$, depending on species) in climatically exposed mountain elevations, planting of seedlings is recommended northbound at the crown perimeter of trees within the existing stand, in order to ensure covering effect alleviating microclimatic parameters' extremes (Balcar et al. 2007). As shown in a previous study (Špulák \& Souček 2010), this location is exposed to lower temperature fluctuations at a height of $40 \mathrm{~cm}$ aboveground. Several studies have compared the microclimate of young forest stands to open space (e.g., Baumgartner 1956, Göhre \& Lützke 1956, Chroust 1973, Chroust 1997), by correlating ground air temperature and temperature at the height of $200 \mathrm{~cm}$ aboveground. On the other hand, no evidence is reported in literature so far on temperatures at various locations of gaps in young forest stands. More detailed knowledge of these relationships would allow to evaluate differences between microclimates at various sites within smallarea clear-cuts in these stands in relation to the size of planting material and the selection of planting placement. This would make it possible to improve the specificity of recommendations for forestry practice, and especially those concerning larger-dimension planting material.

The aim of the study was therefore to evaluate and mutually compare temperature developments at selected aboveground heights 
at the northern and southern margins of the stand edge for a young spruce group in a climatically exposed mountainous site in order to derive recommendations for more successful planting.

\section{Materials and methods}

Temperature development within a 17year-old spruce stand (at small pole stage) was monitored in the upper part of the Jizerka research plot in the Jizerské hory Mountains, Czeck Republic (50 49'34" N lat. and $15^{\circ} 21^{\prime} 19^{\prime \prime} \mathrm{E}$ long.). The site is situated in the summit area of a mild SW slope at an altitude of $980 \mathrm{~m}$ and is classified according to the Czech typological system (Viewegh et al. 2003) as acidic spruce forest with reed $(8 \mathrm{~K} 2)$. The large clearing after salvage felling had been planted in the 1990s with approx. 30 tree species in square plots of 10 x $10 \mathrm{~m}$ with random repetition (Balcar \& Podrázsky 1994, Balcar et al. 2005). Mean annual precipitation at the locality was 1135 $\mathrm{mm}$ in the period 1994-2010 (Balcar et al. 2012a). In the period 1997-2010, mean annual temperature and mean growing period temperature (from May to September) were $5.0{ }^{\circ} \mathrm{C}$ and $12.3{ }^{\circ} \mathrm{C}$, respectively (as measured at a meteorological station situated about $100 \mathrm{~m}$ southwest of the surveyed area). Mean annual global radiation was $3894 \mathrm{MJ}$ $\mathrm{m}^{-2}$ (Balcar et al. 2012b). In 2010, annual precipitation totalled $1561 \mathrm{~mm}$, but mean annual temperature and growing period temperature remained low $\left(3.4^{\circ} \mathrm{C}\right.$ and $11.2{ }^{\circ} \mathrm{C}$, respectively - Balcar et al. 2012a, 2012b). In 2011, annual precipitation was $1234 \mathrm{~mm}$ while mean annual temperature and growing period temperature were $5.1^{\circ} \mathrm{C}$ and $11.8^{\circ} \mathrm{C}$, respectively.

The temperature measurements were taken in a Norway spruce stand planted in 1993, the mean height of which was approximately $4.5 \mathrm{~m}$ and stand density 4000 trees $\mathrm{ha}^{-1}$ in 2010. The forest plot (parcel) of planting size $10 \times 10 \mathrm{~m}$ was located on flat land adjacent to parcels of Carpathian birch (Betula carpatica Willd., mean height approximately $3.2 \mathrm{~m}$ ) on the west and east. To the north and south there were treeless belts $5 \mathrm{~m}$ wide and linking to parcels of spruce (also about $4.5 \mathrm{~m}$ in height).

Temperature recorders (Comet System, Rožnov pod Radhoštem, Czech Republic) were installed near the centers of the stand edge on the southern and northern stand margins at a distance approximately $40 \mathrm{~cm}$ from the crown projections of the two nearest spruce trees. To represent air layers where terminal shoots of different planting stock types would grow (saplings, semi-saplings, seedlings), the sensors were placed at heights of 140, 90, 60 and $30 \mathrm{~cm}$ aboveground. These were designated as S_140, S_90, S_60 and S_30 for the southern margin of the stand edge, and N_140, N_90,
N_60 and N_30 for the northern margin of the stand edge. A reference temperature sensor was placed $30 \mathrm{~cm}$ aboveground in the middle of a belt $5 \mathrm{~m}$ wide, representing conditions of small-sized plants in the stand opening (marked as GAP_30). A sensor installed at $200 \mathrm{~cm}$ aboveground monitored the local temperature at meteorological height (GAP_200). All sensors were screened from direct solar radiation. Ground vegetation at the measurement points and in their vicinity was dominated by reed grass (Calamagrostis villosa (Chaix) J. F. Gmelin), which on both sides grew up to $50 \mathrm{~cm}$ and produced dry matter of approximately $180 \mathrm{~g} \mathrm{~m}^{-2}$.

The measurement system was installed in 2009. Our study evaluates two extended growing seasons from 1 April to 31 October in 2010 and 2011. The measurement interval of 15 min was chosen to represent with sufficient accuracy the fluctuation of temperatures, while considering the thermal dynamics of the sensors and storage capacity of the automatic loggers. This interval was considered also sufficient for detecting the temperature development in relation to the potential risk of temperature stress to trees. With respect to the site character, the period referred to as the regular growing period is from 1 May to 30 September.

To assess the relative accuracy of measurements over time, selected sections of the data series were compared by means of correlation coefficients and graphs, and by mutual comparison of them with data obtained from additional sensors installed in the vicinity of the experiment. The temperature sensor

Tab. 1 - Mean daily temperature (Mean), minimum monthly temperature (Abs. Min.), mean of daily temperature minima (Mean Min.) and mean of daily temperature amplitudes (Mean Ampl.) for each month (IV-X), overall growing season, and experimental period as a whole (Total: IV-X) in a forest gap at heights $200 \mathrm{~cm}$ (GAP_200) and $30 \mathrm{~cm}$ (GAP_30) aboveground $\left({ }^{\circ} \mathrm{C}\right)$.

\begin{tabular}{llcccccccc}
\hline & & \multicolumn{4}{c}{ GAP_200 } & \multicolumn{4}{c}{ GAP_30 } \\
\cline { 2 - 10 } Year & Month & Mean & $\begin{array}{c}\text { Abs. } \\
\text { Min. }\end{array}$ & $\begin{array}{c}\text { Mean } \\
\text { Min. }\end{array}$ & $\begin{array}{c}\text { Mean } \\
\text { Ampl. }\end{array}$ & Mean & $\begin{array}{c}\text { Abs. } \\
\text { Min. }\end{array}$ & $\begin{array}{c}\text { Mean } \\
\text { Min. }\end{array}$ & Mean \\
& & & Ampl. \\
\hline 2010 & IV & 4.6 & -3.8 & 0.7 & 8.9 & 5 & -7.8 & -0.8 & 14.2 \\
& V & 7 & 0.1 & 4.1 & 6.5 & 8 & 0.4 & 4.1 & 9.6 \\
& VI & 12.9 & 3 & 8.1 & 9.9 & 13.5 & 0.1 & 6.4 & 16.4 \\
& VII & 17 & 6.7 & 12.3 & 10.3 & 16.2 & 3.1 & 8.9 & 17.9 \\
& VIII & 13.5 & 4.2 & 10.1 & 7.4 & 14.1 & 3 & 8.9 & 13.4 \\
& IX & 8 & -0.2 & 5.3 & 7.1 & 8.6 & -0.6 & 4 & 12.5 \\
& X & 3.6 & -4.4 & 0.9 & 6.6 & 4.1 & -7 & -0.5 & 11.7 \\
& Growing season (V-IX) & 11.7 & 2.8 & 8 & 8.2 & 12 & 1.2 & 6.4 & 13.9 \\
& Total (IV-X) & 9.5 & 0.8 & 5.9 & 8.1 & 9.9 & -1.3 & 4.4 & 13.6 \\
\hline 2011 & IV & 7.3 & -2.1 & 3.2 & 9.1 & 7.7 & -3.1 & 1.9 & 13.6 \\
& V & 10.2 & -4.5 & 5.1 & 10.6 & 10.8 & -6.1 & 3.2 & 17 \\
& VI & 13.1 & 5.3 & 8.8 & 9.2 & 14.2 & 3.3 & 7.7 & 15.6 \\
& VII & 12.5 & 5 & 9 & 7.7 & 13.4 & 1.6 & 7.9 & 13.6 \\
& VIII & 14.4 & 4.5 & 10.4 & 9.3 & 15 & 0.8 & 8.7 & 16.7 \\
& IX & 11.8 & 4.2 & 8 & 8.4 & 12 & 0.5 & 6 & 15.8 \\
& X & 5.4 & -3.1 & 2.9 & 6.1 & 5.9 & -6.8 & 1.7 & 11.1 \\
& Growing season (V-IX) & 12.4 & 2.9 & 8.3 & 9 & 12.9 & 0 & 6.6 & 15.8 \\
& Total (IV-X) & 10.7 & 1.3 & 6.8 & 8.6 & 11 & -1.4 & 5.1 & 14.7 \\
\hline
\end{tabular}
lings planted in the forest openings and clear-cuts was chosen as reference. Differences between the temperature characteristics (mean temperature, means of daily minima, maxima and temperature amplitudes, number of temperature measurements below the freezing point, etc) in GAP_30 and other tested positions were computed and compared. To compare relative trends of temperature behavior, linear regression models were computed for mean, minimum and maximum temperatures, as explained by the values measured at GAP 30 . The calculations were processed using the Unistat 5.6.01 and R 2.10.1 software (R Foundation for Statistical Computing 2011).

\section{Results}

\section{Mean characteristics}

In line with expectations, ground temperatures in the gap exhibited greater fluctuations than temperatures measured at meteorological height $(200 \mathrm{~cm}$ aboveground). Mean temperature in the growing season was higher at the GAP 30 reference position relative to GAP_200 by $0.3{ }^{\circ} \mathrm{C}(2010)$ and 0.5 ${ }^{\circ} \mathrm{C}$ (2011). The mean of daily minimum temperatures at GAP_30 was lower by about 1.6 ${ }^{\circ} \mathrm{C}$, while the mean amplitude was greater by more than $5.5^{\circ} \mathrm{C}$ as compared with the position of GAP 200 (Tab. 1). The temperatures apparently reflect the different course of weather in the evaluated periods; with the exception of July, the year 2010 was colder than the following year. Differences of mean temperature characteristics at the ground air
GAP_30 representing conditions of seed- 

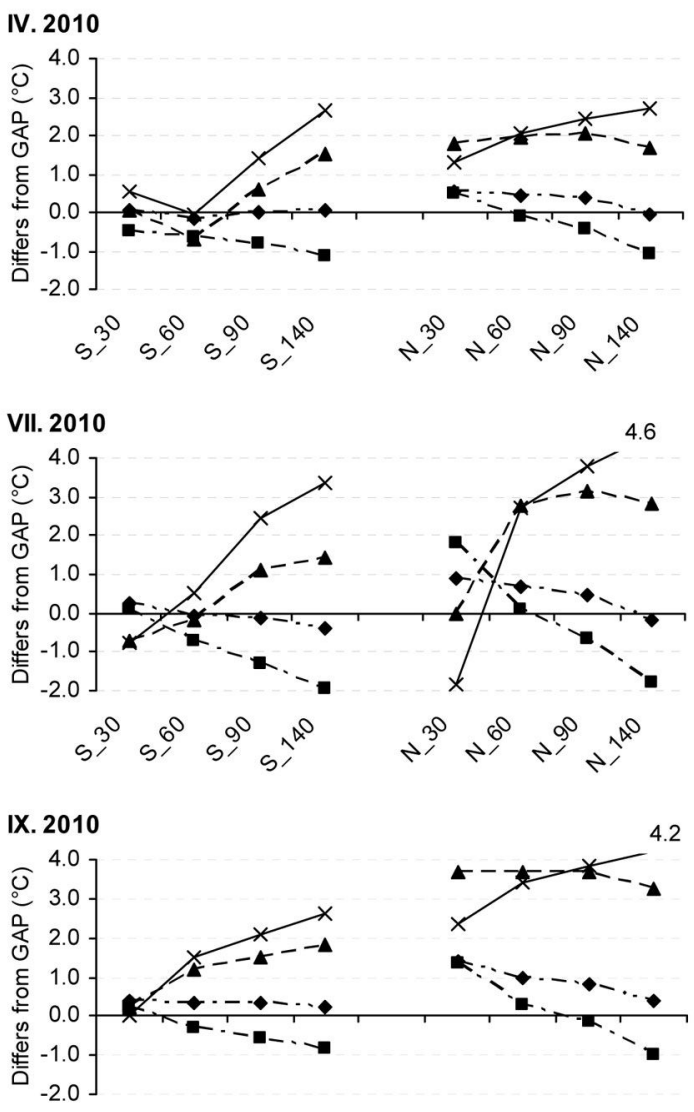

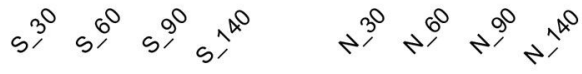

\section{IV. - IX. 2010}
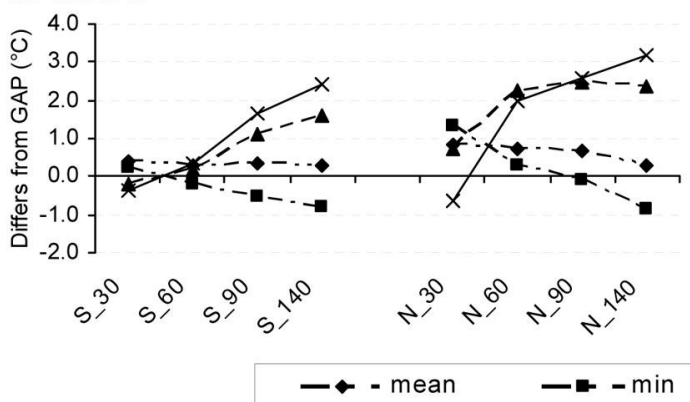

\section{2011}

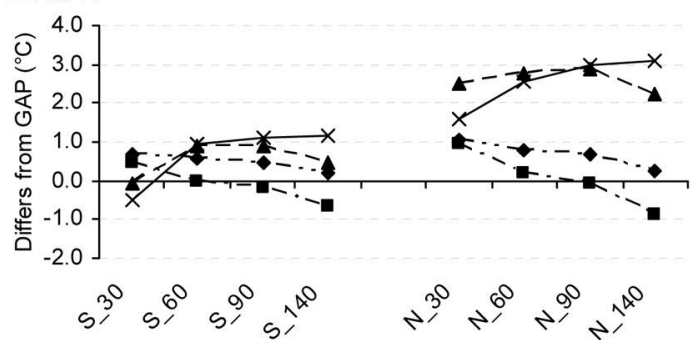

\section{2011}

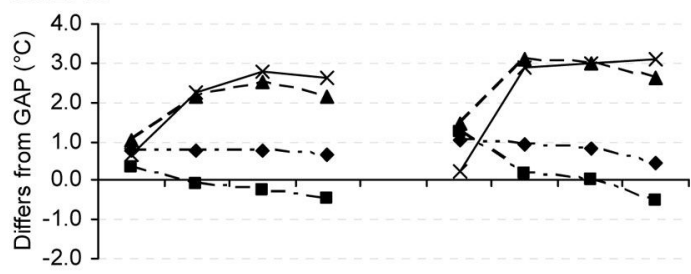

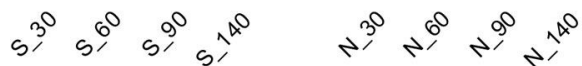

Fig. 1 - Differences of temperature characteristics between the gap and individual aboveground heights of stand margins. Mean differences of daily mean air temperatures, mean differences of daily air temperature minima $(\min )$, maxima $(\max )$ and temperature amplitudes (ampl) between the gap $(30 \mathrm{~cm})$ and southern $(\mathrm{S})$ or northern $(\mathrm{N})$ stand margins at identical heights aboveground $(30,60,90$ and $140 \mathrm{~cm}$ ) in 2010 (left) and 2011 (right). IV: April; VII: July; IX: October; IV-IX: whole period of monitoring.

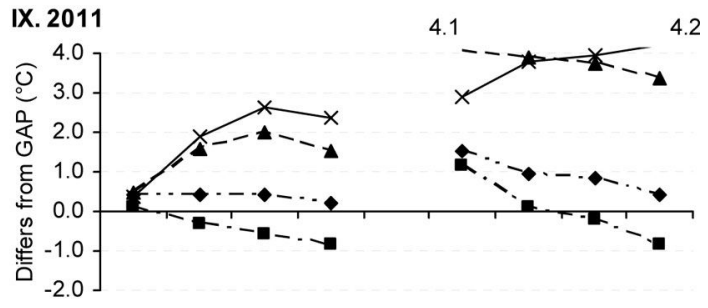

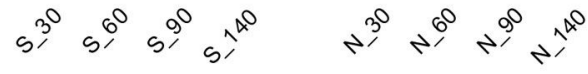

\section{IV. - IX. 2011}

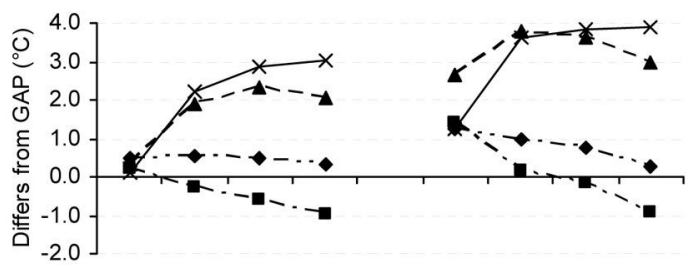

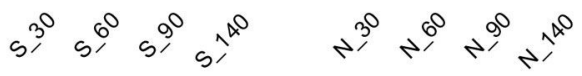

$$
\longrightarrow \text { max } \quad \text { ×ampl }
$$

layer in the stand gap (GAP_30) and at the individual locations within the spruce stand margins were dependent on the year and season, as well as on the actual course of the weather. Considerable fluctuation was observed in values representing extremes (minima, maxima, amplitudes) as compared with the mean values (Fig. 1). Absolute values differed between the two years, but the relative relationships between the values in the respective positions showed an identical trend.

The difference of mean temperatures between GAP_30 and positions at the southern stand margin reached a maximum of 0.5 ${ }^{\circ} \mathrm{C}$ in the surveyed periods $(2010,2011)$, and the gradual decrease of that difference with increasing aboveground height was slow. By contrast, the differences in mean temperatures between GAP_30 and positions at the northern stand margin were decreasing more conspicuously with the increasing height aboveground. The mean temperature of N_30 was lower by about $1{ }^{\circ} \mathrm{C}$, while the temperatures at both heights of $140 \mathrm{~cm}$ aboveground were nearly the same (Fig. 1). From the mean differences between the daily minimum temperatures of GAP 30 and positions at the southern stand margin, it follows that while the minimum temperatures at 30 $\mathrm{cm}$ aboveground were about the same, the minimum temperatures at $140 \mathrm{~cm}$ aboveground at the stand margins were on average about $1{ }^{\circ} \mathrm{C}$ higher than in the reference posi- tion. At the northern stand margin, the minimum temperatures in the GAP 30 position were approached by the temperature values measured at $60-90 \mathrm{~cm}$ aboveground. The minimum ground temperatures in the north were on average lower by more than $1.2{ }^{\circ} \mathrm{C}$ in the study period than those in the reference position (Fig. 1). The differences of mean minimum temperatures at $140 \mathrm{~cm}$ aboveground at the southern and northern stand margins were low in both each single months and the entire periods of study.

The mean differences of daily maximum temperatures were not obviously correlated with height, and the differences between the two monitored periods (2010 and 2011) were also more divergent. The maximum 
Tab. 2 - The number (A) and mean (B) of measured sub-zero temperatures and temperature minima (C) for months, growing season and the experimental period as a whole (Total - IV-X) in the gap at $30 \mathrm{~cm}$ aboveground (GAP_30) and differences between GAP_30 values and temperatures at the southern $(\mathrm{S})$ and northern $(\mathrm{N})$ stand margins at 140, 90, 60 and $30 \mathrm{~cm}$ aboveground. The negative values for differences indicate values higher than GAP_30, while the positive values for differences indicate values lower than GAP_30 (e.g., the difference in number for S_140 in IV 2010 were calculated as follows: $\left.\mathrm{N}_{\mathrm{IV} \_2010\left(\mathrm{GAP}_{-} 30\right)}-\mathrm{N}_{\mathrm{IV} \_2010\left(\mathrm{~S}_{1} \_40\right)}=488-471=17\right)$. The temperatures were recorded at intervals of 15 min. $(*)$ : GAP_30 is given as ${ }^{\circ} \mathrm{C}$ for average (B) and minima (C), and as a number for (A).

\begin{tabular}{|c|c|c|c|c|c|c|c|c|c|c|c|c|c|c|c|c|c|c|c|}
\hline \multirow{3}{*}{ Temp. } & \multirow{3}{*}{ Month } & \multicolumn{9}{|c|}{ Year 2010} & \multicolumn{9}{|c|}{ Year 2011} \\
\hline & & \multicolumn{4}{|c|}{$\begin{array}{l}\text { Southern stand margin } \\
\text { (Diff. from Gap_30) }\end{array}$} & \multirow{2}{*}{$\begin{array}{l}\text { GAP_30* } \\
\left(\mathbf{N}-{ }^{\circ} \mathbf{C}\right)\end{array}$} & \multicolumn{4}{|c|}{$\begin{array}{l}\text { Northern stand margin } \\
\text { (Diff. from Gap_30) }\end{array}$} & \multicolumn{4}{|c|}{$\begin{array}{l}\text { Southern stand margin } \\
\text { (Diff from Gap_30) }\end{array}$} & \multirow{2}{*}{$\begin{array}{l}\text { GAP_30* } \\
\left(\mathbf{N}-{ }^{\circ} \mathbf{C}\right)\end{array}$} & \multicolumn{4}{|c|}{$\begin{array}{l}\text { Northern stand margin } \\
\text { (Diff. from Gap_30) }\end{array}$} \\
\hline & & S_30 & S_60 & S_90 & $\overline{S \_140}$ & & N_30 & N_60 & N_90 & N_140 & S_30 & S_60 & S_90 & S_140 & & N_30 & N_60 & N_90 & N_140 \\
\hline (A) & IV & -38 & -6 & 12 & 17 & 488 & -110 & -48 & -38 & 54 & -120 & -93 & -96 & -100 & 127 & -115 & -83 & -93 & -53 \\
\hline \multirow{8}{*}{ Number } & $\mathrm{V}$ & & & & & 0 & -1 & & & & -32 & -9 & -9 & -9 & 166 & -71 & -20 & -23 & -12 \\
\hline & VI & -6 & & & & 0 & -15 & -2 & & & & & & & 0 & & & & \\
\hline & VII & & & & & 0 & & & & & & & & & 0 & -3 & & & \\
\hline & VIII & & & & & 0 & & & & & & & & & 0 & -30 & & & \\
\hline & IX & -3 & 12 & 12 & 12 & 14 & -115 & -4 & 5 & 12 & & & & & 0 & -36 & & & \\
\hline & $\mathrm{X}$ & -156 & -88 & -13 & 37 & 621 & -274 & -170 & -82 & 83 & -50 & -53 & -58 & -56 & 285 & -141 & -80 & -81 & -42 \\
\hline & $\begin{array}{l}\text { Growing } \\
\text { season (V-IX) }\end{array}$ & -9 & 12 & 12 & 12 & 14 & -131 & -6 & 5 & 12 & -32 & -9 & -9 & -9 & 166 & -140 & -20 & -23 & -12 \\
\hline & Total & -203 & -82 & 11 & 66 & 1123 & -515 & -224 & -115 & 149 & -202 & $-155-$ & -163 & -165 & 578 & -396 & -183 & -197 & -107 \\
\hline (B) & IV & -0.4 & -0.4 & -0.4 & -0.5 & -2 & 0 & -0.2 & -0.3 & -0.5 & 0 & -0.1 & 0 & -0.1 & -0.9 & 0 & -0.1 & -0.1 & -0.2 \\
\hline \multirow[t]{8}{*}{ Average } & $\mathrm{V}$ & & & & & & 0.4 & & & & 0.2 & 0.1 & -0.1 & -0.3 & -2.5 & 0.3 & 0.2 & 0 & -0.4 \\
\hline & VI & 0.4 & & & & & 0.5 & 0.2 & & & & & & & & & & & \\
\hline & VII & & & & & & & & & & & & & & & 0.2 & & & \\
\hline & VIII & & & & & & & & & & & & & & & 0.8 & & & \\
\hline & IX & 0 & 0.2 & 0.1 & 0.2 & -0.3 & 0.5 & 0.1 & 0 & 0 & & & & & & 0.5 & & & \\
\hline & $\mathrm{X}$ & -0.1 & -0.4 & -0.5 & -0.4 & -2 & 0.4 & -0.3 & -0.4 & -0.5 & -0.6 & -1 & -1.1 & -1.3 & -2.6 & 0.4 & -0.5 & -0.7 & -1.2 \\
\hline & $\begin{array}{l}\text { Growing } \\
\text { season (V-IX) }\end{array}$ & 0 & 0.2 & 0.1 & 0.2 & -0.3 & 0.4 & 0.1 & 0 & 0 & 0.2 & 0.1 & -0.1 & -0.3 & -2.5 & -0.2 & 0.2 & 0 & -0.4 \\
\hline & Total (I & -0.2 & -0.4 & -0.4 & -0.4 & -2 & 0.1 & -0.3 & -0.4 & -0.5 & -0.4 & -0.6 & -0.7 & -0.8 & -2.2 & 0 & -0.3 & -0.5 & -0.8 \\
\hline (C) & IV & -2 & -1.9 & -1. & -2 . & & -0.2 & -0.8 & -1 . & -3 & 0.4 & -0.6 & -0.6 & & -3.1 & 0.7 & -0.7 & -0 & -1.3 \\
\hline \multirow[t]{8}{*}{ Minima } & $\mathrm{V}$ & 0 & 0 & 0.1 & 0.2 & 0 & 0.8 & 0.1 & 0.2 & 0 & & 0 & -0 & -0 & -6. & 3.1 & 1.1 & 0.5 & -0.9 \\
\hline & VI & 0.8 & -0.4 & -0.6 & -2 & 0 & 1.3 & 0.3 & -0.7 & -1.9 & 0.1 & -0.9 & -1.1 & -1 . & 3.3 & 1.7 & -0.1 & -1.2 & -2.3 \\
\hline & VII & 1.2 & -0.7 & -1.5 & -3.1 & 3 & 2.5 & -0.1 & -1.4 & -3 & 0.1 & -1.2 & -1.5 & -1 & 1.6 & 1.8 & -0.5 & -0.9 & -1.6 \\
\hline & VI & 0 & -0.3 & -0. & -0.5 & 3 & 1. & 0.1 & -0.1 & -0 & 0 . & -0.8 & -1 & -1 & 0 . & 2.2 & 0 & -0 & -1.6 \\
\hline & IX & 0 & 0 & -0.2 & 0 & -0.6 & 1.7 & 0.4 & 0 & -0 . & 0.3 & -1.2 & -1.7 & -2 & 0.5 & 1.5 & -0.6 & -1.5 & -2.2 \\
\hline & $\mathrm{X}$ & 0.4 & -0.5 & -0.9 & -1.9 & -7 & 2.4 & 0.8 & 0.3 & -1 . & -0.8 & -2.2 & -2.4 & -2.6 & -6.8 & 1 & -1.4 & -1.8 & -2.8 \\
\hline & $\begin{array}{l}\text { Growing } \\
\text { season (V-IX) }\end{array}$ & 0.1 & 0 & -0.2 & 0 & -0.6 & 1.7 & 0.4 & 0 & -0.1 & 2.2 & 0 & -0.1 & -0.7 & -6.1 & 3.1 & 1.1 & 0.5 & -0.9 \\
\hline & Total (IV-X) & -0.4 & -1.3 & -1.7 & -2.7 & -7.8 & 1.6 & 0 & -0.5 & -2.4 & 1.5 & -0.7 & -0.8 & -1.4 & -6.8 & 2.4 & 0.4 & -0.2 & -1.6 \\
\hline
\end{tabular}

temperatures of S_30 were nearly identical with the temperatures in the gap, while in other locations they were lower (Fig. 1).

The mean differences of daily amplitudes, reflecting the course of minimum and maximum temperatures, exhibited considerable fluctuations. The temperature amplitudes of S_30 were close to the reference values. A conspicuous difference between the years was recorded at the northern stand margin. On average, for the entire periods of study positive correlation was observed between amplitude differences and height aboveground; some exceptions did occurred in individual months, however, namely at the southern stand margin (Fig. 1).

\section{Temperatures below the freezing point}

Temperatures below the freezing point occurred at the studied locality each month in at least one of the two assessed periods $(2010,2011$ - Tab. 2A). As to their frequency of occurrence, the highest number of measurements with sub-zero temperatures was recorded in the position $\mathrm{N} 30$, followed by S_30 and N_60. As compared with
GAP_30, the numbers of sub-zero temperatures measured higher aboveground at the stand margins differed in the respective years. Differences in the numbers of subzero temperature values between the positions N_140 and S_140 in the growing period were relatively small.

The mean temperatures below the freezing point measured in the GAP 30 position reached $-2.6{ }^{\circ} \mathrm{C}$ (October 2011). The difference of mean sub-zero temperature values in this reference position and in other monitored positions usually fluctuated within a range of $0.5^{\circ} \mathrm{C}$ (Tab. 2B).

The monthly minimum temperatures at 30 $\mathrm{cm}$ aboveground at the stand margins were mostly lower than in the reference position (Tab. 2C). Minimum temperatures lower than in the reference position were recorded also in position N 60, especially in 2010 . Minimum temperatures measured at greater heights aboveground were mostly higher. Differences in the monthly minimum temperatures between the heights of $140 \mathrm{~cm}$ aboveground (S 140 and N 140) ranged up to $0.3{ }^{\circ} \mathrm{C}$ (Tab. 2C), with one exception
(June 2011). The differences between the respective heights were increasing with the decreasing height aboveground.

\section{Linear regression models}

Results of the linear regression of variables (mean, minimum and maximum daily temperatures) inherent to positions at stand margins in relation to GAP_30 reference values demonstrated certain regularities depending on the location and height aboveground. Parameters of all regression models for mean daily temperatures were highly significant. The intercept of linear regression lines for the positions at the northern stand margin was rising with the increasing height aboveground; the same observation holds also for the positions at the southern stand margin in 2011 (Tab. 3). With one exception (southern margin in 2011), the slope of linear regression lines for mean temperatures was ascending with the increasing height aboveground at both stand margins. Parameters of the linear regression line for position N 140 was in 2010 nearly identical with that of position S_90. In the following year, conformity of 
Tab. 3 - Linear regression models (intercept and slope) for daily mean (A), minimum (B) and maximum temperatures (C) in the respective positions explained by values measured at $30 \mathrm{~cm}$ in the forest gap (GAP). The southern (S) and northern (N) stand margins at 30, 60, 90 and $140 \mathrm{~cm}$ aboveground are marked as S_30, N_30,.., S_140, N_140.

\begin{tabular}{|c|c|c|c|c|c|c|c|c|c|c|}
\hline \multirow{2}{*}{ Temp. } & \multirow{2}{*}{ Margins } & \multirow{2}{*}{ Parameters } & \multicolumn{4}{|c|}{2010} & \multicolumn{4}{|c|}{2011} \\
\hline & & & Estimate & SE & $\operatorname{Pr}(>|t|)$ & Adj. $R^{2}$ & Estimate & SE & $\operatorname{Pr}(>|t|)$ & Adj. $R^{2}$ \\
\hline (A) & S_30 & (Intercept) & -0.4 & 0.06 & $<0.001$ & 0.994 & -0.71 & 0.08 & $<0.001$ & 0.991 \\
\hline \multirow[t]{15}{*}{ Means } & & Mean_GAP (Slope) & 1 & 0.01 & $<0.001$ & & 1.02 & 0.01 & $<0.001$ & \\
\hline & S_60 & (Intercept) & -0.37 & 0.08 & $<0.001$ & 0.991 & -0.59 & 0.08 & $<0.001$ & 0.992 \\
\hline & & Mean_GAP (Slope) & 1.01 & 0.01 & $<0.001$ & & 1.01 & 0.01 & $<0.001$ & \\
\hline & S_90 & (Intercept) & -0.46 & 0.08 & $<0.001$ & 0.99 & -0.61 & 0.09 & $<0.001$ & 0.99 \\
\hline & & Mean_GAP (Slope) & 1.02 & 0.01 & $<0.001$ & & 1.01 & 0.01 & $<0.001$ & \\
\hline & S_140 & (Intercept) & -0.53 & 0.11 & $<0.001$ & 0.982 & -0.5 & 0.14 & $<0.001$ & 0.976 \\
\hline & & Mean_GAP (Slope) & 1.03 & 0.01 & $<0.001$ & & 1.02 & 0.01 & $<0.001$ & \\
\hline & N_30 & (Intercept) & -0.79 & 0.08 & $<0.001$ & 0.99 & -0.9 & 0.13 & $<0.001$ & 0.978 \\
\hline & & Mean_GAP (Slope) & 0.99 & 0.01 & $<0.001$ & & 0.97 & 0.01 & $<0.001$ & \\
\hline & N_60 & (Intercept) & -0.59 & 0.05 & $<0.001$ & 0.996 & -0.72 & 0.06 & $<0.001$ & 0.995 \\
\hline & & Mean_GAP (Slope) & 0.99 & 0 & $<0.001$ & & 0.98 & 0 & $<0.001$ & \\
\hline & N_90 & (Intercept) & -0.68 & 0.06 & $<0.001$ & 0.994 & -0.78 & 0.06 & $<0.001$ & 0.995 \\
\hline & & Mean_GAP (Slope) & 1 & 0.01 & $<0.001$ & & 1 & 0.01 & $<0.001$ & \\
\hline & N_140 & (Intercept) & -0.45 & 0.09 & $<0.001$ & 0.988 & -0.5 & 0.09 & $<0.001$ & 0.99 \\
\hline & & Mean_GAP (Slope) & 1.02 & 0.01 & $<0.001$ & & 1.02 & 0.01 & $<0.001$ & \\
\hline (B) & S_30 & (Intercept) & 0.01 & 0.06 & 0.919 & 0.985 & -0.17 & 0.06 & 0.011 & 0.982 \\
\hline \multirow[t]{15}{*}{ Minima } & & Min_GAP (Slope) & 0.97 & 0.01 & $<0.001$ & & 0.99 & 0.01 & $<0.001$ & \\
\hline & S_60 & (Intercept) & 0.43 & 0.07 & $<0.001$ & 0.973 & 0.46 & 0.08 & $<0.001$ & 0.968 \\
\hline & & Min_GAP (Slope) & 0.97 & 0.01 & $<0.001$ & & 0.96 & 0.01 & $<0.001$ & \\
\hline & S_90 & (Intercept) & 0.7 & 0.1 & $<0.001$ & 0.95 & 0.74 & 0.11 & $<0.001$ & 0.946 \\
\hline & & Min_GAP (Slope) & 0.97 & 0.02 & $<0.001$ & & 0.96 & 0.02 & $<0.001$ & \\
\hline & S_140 & (Intercept) & 1.06 & 0.13 & $<0.001$ & 0.914 & 1.25 & 0.15 & $<0.001$ & 0.899 \\
\hline & & Min_GAP (Slope) & 0.95 & 0.02 & $<0.001$ & & 0.93 & 0.02 & $<0.001$ & \\
\hline & N_30 & (Intercept) & -0.97 & 0.09 & $<0.001$ & 0.96 & -1.25 & 0.09 & $<0.001$ & 0.964 \\
\hline & & Min_GAP (Slope) & 0.94 & 0.01 & $<0.001$ & & 0.99 & 0.01 & $<0.001$ & \\
\hline & N_60 & (Intercept) & -0.03 & 0.06 & 0.680 & 0.979 & -0.01 & 0.07 & 0.927 & 0.976 \\
\hline & & Min_GAP (Slope) & 0.95 & 0.01 & $<0.001$ & & 0.97 & 0.01 & $<0.001$ & \\
\hline & N_90 & (Intercept) & 0.41 & 0.09 & $<0.001$ & 0.961 & 0.41 & 0.1 & $<0.001$ & 0.958 \\
\hline & & Min_GAP (Slope) & 0.94 & 0.01 & $<0.001$ & & 0.95 & 0.01 & $<0.001$ & \\
\hline & N_140 & (Intercept) & 1.17 & 0.12 & $<0.001$ & 0.926 & 1.27 & 0.13 & $<0.001$ & 0.922 \\
\hline & & Min_GAP (Slope) & 0.94 & 0.02 & $<0.001$ & & 0.93 & 0.02 & $<0.001$ & \\
\hline (C) & S_30 & (Intercept) & -0.77 & 0.24 & 0.002 & 0.972 & -0.65 & 0.32 & 0.044 & 0.959 \\
\hline \multirow[t]{15}{*}{ Maxima } & & Max_GAP (Slope) & 1.05 & 0.01 & $<0.001$ & & 1.02 & 0.02 & $<0.001$ & \\
\hline & S_60 & (Intercept) & -0.3 & 0.27 & 0.27 & 0.963 & -0.05 & 0.25 & 0.857 & 0.967 \\
\hline & & Max_GAP (Slope) & 1.01 & 0.01 & $<0.001$ & & 0.92 & 0.01 & $<0.001$ & \\
\hline & S_90 & (Intercept) & -0.33 & 0.21 & 0.117 & 0.975 & -0.08 & 0.27 & 0.763 & 0.962 \\
\hline & & Max_GAP (Slope) & 0.96 & 0.01 & $<0.001$ & & 0.9 & 0.01 & $<0.001$ & \\
\hline & S_140 & (Intercept) & -0.63 & 0.24 & 0.008 & 0.967 & -0.18 & 0.33 & 0.582 & 0.947 \\
\hline & & Max_GAP (Slope) & 0.94 & 0.01 & $<0.001$ & & 0.92 & 0.02 & $<0.001$ & \\
\hline & N_30 & (Intercept) & -2.12 & 0.4 & $<0.001$ & 0.925 & -0.75 & 0.51 & 0.145 & 0.872 \\
\hline & & Max_GAP (Slope) & 1.05 & 0.02 & $<0.001$ & & 0.89 & 0.02 & $<0.001$ & \\
\hline & N_60 & (Intercept) & -0.57 & 0.33 & 0.086 & 0.933 & -0.18 & 0.39 & 0.649 & 0.908 \\
\hline & & Max_GAP (Slope) & 0.9 & 0.02 & $<0.001$ & & 0.82 & 0.02 & $<0.001$ & \\
\hline & N_90 & (Intercept) & -0.7 & 0.32 & 0.029 & 0.936 & -0.3 & 0.39 & 0.444 & 0.911 \\
\hline & & Max_GAP (Slope) & 0.9 & 0.02 & $<0.001$ & & 0.84 & 0.02 & $<0.001$ & \\
\hline & N_140 & (Intercept) & -0.52 & 0.29 & 0.071 & 0.948 & -0.23 & 0.38 & 0.548 & 0.919 \\
\hline & & Max_GAP (Slope) & 0.9 & 0.01 & $<0.001$ & & 0.86 & 0.02 & $<0.001$ & \\
\hline
\end{tabular}

the resulting coefficients of the two linear lines was recorded at $140 \mathrm{~cm}$ aboveground (N_140 and S_140).

Coefficients for the models of minimum daily temperatures in the individual locations were highly significant with the exception of intercepts for the positions S_30 and N_60. The intercepts of the regression lines of positions at both stand margins were rising with the increasing height aboveground, with that rise being more distinctive at the northern stand margin. The slope of the models was in 2010 almost constant regardless of height aboveground, while is descending with increasing height in 2011. Coefficients from the models of minimum temperatures for N_140 and S_140 were very close in 2010 and identical in 2011.

The intercepts of linear regression lines for daily maximum temperatures often differed insignificantly from 0 , most notably in the year 2011 (Tab. 3). Slopes of the models did not exhibit a uniform trend in relation to height aboveground. Closeness of the mutual relationship between the daily maximum temperatures of the reference position and the tested positions was slightly lower than in the case of daily mean and minimum temperatures. 


\section{Discussion}

Besides the location and stand parameters, weather is another main factor affecting the course of air temperatures in the individual locations within the stand or the stand gap (Latif \& Blackburn 2010). The course of temperatures within the stand positions becomes more uniform on cloudy days. Even more stabilizing elements are high air humidity and precipitation. The passing of incoming direct radiation through shading elements leads to non-homogeneous heating of the environment, and this phenomenon becomes more distinctive under conditions of variable cloudiness. The ecosystem receives thermal energy from direct and reflected long-wave solar radiation, the amount of which is proportional to radiation intensity as well as to absorptive and reflective properties of the vegetation cover and soil (Panferov et al. 2001). Flowing air also contributes to heat penetration, as windy weather helps to equalize air temperature in the environment.

Heating rate during the day and thermal radiation during the night are conditioned in the ground air layers by the characteristics of the soil surface (Groot et al. 1997). On the transition between the stand environment and the clear-cut area, a marginal effect may be manifested by the gradients of meteorological elements (Davies-Colley et al. 2000). The development of herbaceous vegetation in spring and its senescence during autumn change the capacity for heat accumulation and transmission in soil, since the forest floor and the lower atmosphere appear to be coupled (Beltrami \& Kellman 2003). The layer of dead grass reduces thermal conductivity of the soil surface, thus causing the occurrence of temperature extremes at noon and overnight. This phenomenon is rather undesirable, particularly in forestry (Geiger 1950). On the other hand, the humus layer prevents freezing of the soil during hard frosts. The vegetation cover on both the southern and northern margins of the spruce stand in our experiment was dominated by C. villosa at about the same density. The stand of reed grass and the turf at both margins had approximately the same characteristics, reflecting heat into higher air layers.

Over the period of this investigation, we observed a colder course of temperatures at the northern stand margin, as minimum, maximum and mean ground temperatures were lower and temperatures below the freezing point occurred more frequently. On the other hand, the temperature amplitudes were lower as compared with the same heights aboveground at the southern stand margin, thus indicating a more stable microclimate. In principle, this finding corresponds with the results of monitoring on a clear-cut area in a mature spruce stand as reported by Radler et al. (2010).
Chroust (1997) reports that temperature differences between a spruce small pole forest and non-stocked forest land are greatest in the ground layer and that they are diminishing with increasing height until they finally cease to exist. This observation corresponds with the reduction of differences between temperature characteristics at the southern and northern stand margins with increasing height aboveground that was observed in our study. As compared with open area, tree crowns in a stand prevent not only heating of the soil but also its cooling (Göhre \& Lützke 1956), which indicates that a more distinctive diminution of differences in cumulative temperature characteristics can occur only in the upper storey of the crown space. As to the height and character of the surveyed stand, the height of $140 \mathrm{~cm}$ aboveground represented a location in which the distinctive lessening of temperature differences between the southern and northern stand margins was already well apparent.

The lower mean temperatures in the growing season at the northern stand margin as well as the lower temperature amplitudes correspond with the temperatures recorded at $40 \mathrm{~cm}$ aboveground at the crown perimeter of solitary young spruce tree in the Krkonoše Mountains (Špulák \& Souček 2010). In the mentioned study, two-thirds fewer temperatures below the freezing point were recorded at the northern face of the spruce crown as compared with the southern face. Moreover, the mean of minimum daily temperatures was higher at the northern crown perimeter, while the mean of daily maximum temperatures was lower. The same effect was observed in that study also at a distance of 60 $\mathrm{cm}$ from the crown perimeter. These findings are in contradiction with the results of the present work. Nevertheless, in contrast to monitoring temperatures in the close vicinity of a solitary standing spruce tree (Špulák \& Souček 2010), we assessed temperatures near the middle of the stand margin of a square-shaped spruce plot. The planting width was $10 \mathrm{~m}$ and the effective width of the spruce group is further increased by the length of branches. Unlike a solitary spruce tree, the group of spruce trees creates a compact whole restricting the penetration of direct solar radiation to its northern margin. Thus, in accordance with principles described in clear-cut areas of mature stands (Carlson 1997, Aussenac 2000), the amount of potential direct solar radiation is lower as compared with the southern margin. This is why the soil surface on the northern edge of the tree groups is less heated in the period of solar irradiation, and at the same time the temperature decrease is greater in that period when long-wave radiation from the terrestrial surface prevails over incoming radiation (especially overnight). At the southern edge, we can expect also the influence of more frequent irradiation on heat accumulation by crown surfaces of individual spruce trees. These effects will decrease with the increasing distance from the stand margins towards the gap.

In contrast to the actual situation within a gap or a small clear-cut area, we assessed only the effect of the southern and northern stand margins in our experiment. The course of temperatures on a small clear-cut area in a homogeneous young stand will be affected also by shading by the eastern and western stand margins (Geiger 1950, Cihal \& Jurča 1961, Krečmer 1960, Radler et al. 2010). Therefore, as compared with our study, smaller differences between the characteristics at the southern and northern margins can be assumed depending on size and shape of the clear-cut area. Specific light (and hence temperature) conditions occur on sloping terrains (Fu \& Rich 2002), the configuration of which has to be taken into account in the localization and shape of clearcut areas.

The species composition of mountain forests has been impoverished in many parts of Europe due to air pollution and past forest management practices. Introduction of additional tree species to enrich the current dominantly coniferous (often spruce) forests is very difficult on mountain summit plateau, and it has repeatedly failed at numerous sites. One of the factors significantly hampering forest regeneration at higher mountain elevations and in frost hollows is the occurrence of temperatures below the freezing point outside the winter period, e.g., late ground frosts (Aussenac 2000).

An ecologically desirable species admixture is often much more susceptible to climate and more sensitive to soils. Those species of central European mountain elevations most sensitive to damage by late frost in the juvenile stage include European ash, sycamore maple, European beech and European silver fir, while Norway spruce is also damaged (Lokvenc et al. 1992, Vacek \& Balcar 2000, Kreyling et al. 2012). Considering the higher occurrence of climate extremes in the ground air layers, many authors recommend to use a planting stock of larger size (semisaplings, saplings) whose terminal shoot is theoretically outside the zone of extreme (especially temperature) stresses (Kuneš et al. 2011).

Planting nursery-raised stock of larger dimensions (semi-saplings and saplings) entails increased costs of planting material and of the planting activity itself (Menzies \& Arnott 1992, Burda \& Nárovcová 2009), due to the necessity to provide mechanical stabilization of plants at higher mountain elevations (Baláš et al. 2011). However, the expected increase in survival and growth (given by the position of the terminal shoot higher above the ground) allows planting 
lower numbers of individuals per hectare with an even distribution over the area. Moreover, the subsequent check of planting prosperity can be markedly easier. From a long-term viewpoint, the selection of advanced planting material in reconstructing young stands of substitute tree species in mountains can be recommended as a biologically and economically efficient practice.

\section{Conclusions}

Based on the measurement of air temperatures in two subsequent years at selected heights aboveground on the clear-cut area and at the northern and southern margins of a young spruce stand whose height was ca $4.5 \mathrm{~m}$, the following conclusions may be drawn:

- Mean air temperature at $140 \mathrm{~cm}$ aboveground on the northern margin of the 17 year old spruce stand during the growing season (May-September) in 2010 and 2011 was $12.2{ }^{\circ} \mathrm{C}$ and was nearly the same temperature observed at the southern margin. Mean temperatures at lower heights aboveground $(90,60$ and $30 \mathrm{~cm}$ ) were gradually decreasing, while that decrease at the northern stand margin was the more distinctive.

- Difference in the course of daily temperature up to $30 \mathrm{~cm}$ aboveground between gap center and its southern margin was small. Nevetheless, a stabilization effect was observed at closer distance from souther margin. The ground air layer at the northern stand margin was markedly colder and showed significantly lower temperature fluctuations than that observed at the southern stand margin.

- Decreasing temperature fluctuation was observed with increasing height aboveground. The frequency and intensity of ground frosts over the growing season was also decreasing with the distance from the ground. As a consequence, we infer that the use of smaller-sized planting material at exposed sites may present a considerable risk of damage by climatic stresses.

- At a height of $140 \mathrm{~cm}$ aboveground (about one-third of the spruce stand height) small differences were observed between southern and northern gap margins as for the daily mean, maximum and minimum temperatures during the growing season. The frequency of late or early frosts was also comparable at the two margins. Based on the above evidence, the choice of suitable planting sites within a small clear-cut area is relevant only when small-sized planting stock are used.

The results of this investigation may contribute to the decision-making process in forestry with particular regard to planting stock size and the locations of planting in relation to the requirements and susceptibility of tree species during reconstructions of young coniferous stands in mountains or during the modification of such stands' species compositions. Our findings will be particularly useful in relation to planting tree species susceptible to temperature stress.

\section{Acknowledgments}

The study was supported under NAZV project QJ1230330 - Stabilization of forest ecosystems by balanced proportion of natural and artificial reforestation.

\section{References}

Aussenac G (2000). Interactions between forest stands and microclimate: ecophysiological aspects and consequences for silviculture. Annals of Forest Science 57: 287-301. - doi: 10.1051/ forest:2000119

Balcar V, Kacálek D (2003). Vyzkum optimálního prostorového usporádání bukovych vysadeb pri premenách porostu náhradních drevin $\mathrm{v}$ Jizerskych horách. [Investigation of European beech plantation optimal spacing for substitute tree species stand conversions in the Jizerské hory Mts.]. Zprávy lesnického vyzkumu 48: 53-61.[in Czech with English summary]

Balcar V, Kacálek D (2008). European beech planted into spruce stands exposed to climatic stresses in mountain areas. Austrian Journal of Forest Science 125: 27-38.

Balcar V, Podrázsky V (1994). Zalození vysadbového pokusu $\mathrm{v}$ hrebenové partii Jizerskych hor. [Establishment of a tree planting experiment in the ridge part of the Jizerské hory Mts]. Zprávy lesnického vyzkumu 39: 1-7. [in Czech with English summary]

Balcar V, Kacálek D, Kuneš I, Podrázsky V (2005). Jizerka study area. In: "Forestry management in the Jizerské hory Mts. Field trip. Jizerské hory Mts" (Neuhöferová P ed). Czech University of Agriculture (Prague - Czech Republic) 27 September 2005, Forestry and Game Management Research Institute, Opočno, Czech Republic, pp. 11-19.

Balcar V, Slodičák M, Kacálek D, Navrátil P (2007). Metodika postupu premen porostu náhradních drevin v imisních oblastech. [Conversion methods of the substitute tree species stands in air polluted areas]. Vyzkumny ústav lesního hospodárství a myslivosti, Strnady, Czech Republic, pp. 34. [in Czech with English summary]

Balcar V, Špulák O, Kacálek D, Kuneš I (2012a). Klimatické podmínky na vyzkumné ploše Jizerka. I - srázky a pudní vlhkost. [Climatic conditions in the Jizerka experimental plot - I. Precipitation and soil moisture]. Zprávy lesnického vyzkumu 57: 74-81. [in Czech with English summary]

Balcar V, Špulák O, Kacálek D, Kuneš I. (2012b). Klimatické podmínky na vyzkumné ploše Jizerka. II - teplota, vítr a sluneční svit. [Climatic conditions in the Jizerka experimental plot. II Temperature, wind and radiation]. Zprávy lesnického vyzkumu 57: 165-177. [in Czech with English summary]
Baláš M, Kuneš I, Šrenk M, Konasová T (2011). Casova a pracovni narocnost vysadby prostokorennych odrostku listnatych drevin $\mathrm{v}$ horskych polohách. [Time requirements and work standards related to planting of bare-rooted saplings of broadleaves on mountain sites]. Zprávy lesnického vyzkumu 56: 235-243. [in Czech with English summary]

Baumgartner A (1956). Über die Unterschiede in den klimatischen Wuchsbedingungen einer freien und einer birkenüberstellten Wiederaufforstungsfläche, Forstwissenschaftliches Centralblatt 7-8: 223-239. [in German]

Beltrami H, Kellman L (2003). An examination of short- and long-term air-ground temperature coupling. Global and Planetary Change 38: 291303. - doi: 10.1016/S0921-8181(03)00112-7

Burda P, Nárovcová J (2009). Overování technologie pestování poloodrostku a odrostku $\mathrm{v}$ lesních školkách. [Testing of the technology for production of large-sized planting stock in forest nurseries]. Zprávy lesnického vyzkumu 54: $92-$ 98. [in Czech with English summary].

Carlson D (1997). Microclimate of clear-cut, forest interior, and small openings in trembling aspen forest. Agricultural and Forest Meteorology 87 (4): 313-329. - doi: 10.1016/S01681923(95)02305-4

Chen J, Frankin JF, Spies TA (1993). Contrasting microclimates among clearcut, edge and interior of old-growth Douglas-fir forest. Agricultural and Forest Meteorology 63: 219-237. - doi: 10.1016/0168-1923(93)90061-L

Chroust L (1973). Vliv schematickych vychovnych zásahu na mikroklima borové mlaziny. [Impact of schematic tending on microclimate of young pine stand]. Lesnictví 19: 567-582.

Chroust L (1997). Ekologie vychovy lesních porostu. [The ecology of forest tending]. Vyzkumny ústav lesního hospodárství a myslivosti Jílovište-Strnady. [in Czech with English summary].

Cihal A, Jurča J (1961). Príspevek k otázce vyuzívání údaju o délkách stínu a podzárení pri obnovách lesních porostu. [Contribution to the question of the use of data on lengths of shadows and sub-forest illumination for renewal of forests]. Sborník vysoké školy zemedelské v Brne, Casopis pro zverejnování vedecké činnosti učitelu a studentu 1-2: 21-31. [in Czech with English summary]

Davies-Colley RJ, Payne GW, Elswijk M (2000). Microclimate gradients across a forest edge. New Zealand Journal of Ecology 24: 111-121.

El Kateb H, Benabdellah B, Ammer Ch, Mosandl R (2004). Reforestation with naive tree species using site preparation techniques for the restoration of woodlands degraded by air pollution in the Erzgebirge, Germany. Eurpean Journal of Forest Research 123: 117-126.

Flemming G (1987). Wald - Wetter - Klima, Einführung in die Forstmeteorologie. VEB Deutscher Landwirtschaftsverlag, Berlin, Germany. [in German]

Fottová D, Skorepová I (1998). Changes in mass element fluxes and their Importance for critical 
loads: Geomon Network. Water, Air and Soil Pollution 105: 365-376. - doi: 10.1023/A:10050 56215068

Fu P, Rich PM (2002). A geometric solar radiation model with applications in agriculture and forestry. Computers and Electronics in Agriculture 37: 25-35. - doi: 10.1016/S0168-1699(02) 00115-1

Geiger R (1950). The climate near the ground. Harvard University Press, Cambridge, MS, USA. Groot A, Carlson DW, Fleming RL, Wood JU (1997). Small openings in trembling aspen forest: microclimate and regeneration of white spruce and trembling aspen. NODA/NFP Technical Representative TR-47, Nat. Resour. Can., Canadian Forest Service Great Lakes Forestry Centre, Sault St. Marie, Ontario, Canada, pp. 25. Göhre K, Lützke R (1956). Der Einfluß von Bestandesdichte und -struktur auf das Kleinklima im Walde. Archiv für Forstwesen 5: 487-572. [in German]

Hering S, Irrgang S (2005). Conversion of substitute tree species stands and pure spruce stands in the Ore Mountains in Saxony. Journal of Forest Science 11: 519-525. [online] URL: http://agriculturejournals.cz/publicFiles/55267.pdf

Huss J (1993). Waldbau vor neuen Herausforderungen bei Waldverjüngung und Jungbestandspflege. Forstwissenschaftliches Centralblatt, pp. 278-286. [in German]

Kreyling J, Thiel D, Nagy L, Jentsch A, Huber G, Konnert M, Beierkuhnlein C (2012). Late frost sensitivity of juvenile Fagus sylvatica L. differs between southern Germany and Bulgaria and depends on preceding air temperature. European Journal of Forest Research 131: 717-725. - doi: 10.1007/s10342-011-0544-y

Krečmer V (1960). Mikroklimaticky a vodní rezim borovych kotlíku. I. Part. [Microclimate and hydrology of the pine clearings. I. Part]. Práce vyzkumnych ústavu lesnickych CSR 19: 7-208. [in Czech with English summary]

Krečmer V (1982). Bioklimatické zmeny na obnovních sečích v imisních oblastech, [Bioclimate changes of regeneration fellings in air-pollution areas]. In: "Obnova lesa v imisních oblastech" (Skala L ed). Ceskoslovenská Akademie Zemedelská, Prague, Czech Republic, pp. 63-68. [in Czech with English summary]

Kuneš I, Baláš M, Millerová K, Balcar V (2011). Vnášení listnaté prímesi a jedle do jehličnatych porostu Jizerskych hor. Certifikovaná metodika [Mountain forest renewal on sites affected by extreme frost stress. Approved methodology]. Lesnicky pruvodce 9 . Vyzkumny ústav lesního hospodárství a myslivosti, Strnady, Czech Republic, pp. 50. [in Czech with English summary]

Küßner R, Mosandl R (2002). Conceptions for converting the forests in the Ore Mts. into ecologically managed ecosystems, $\mathrm{In}$ : " $\mathrm{SO}_{2}$ pollution and forest decline in the Ore Mountains" (Lom- sky B, Materna J, Pfanz H eds). Forestry and Game Management Research Institute, JílovišteStrnady, Czech Republic, pp. 326-342.

Langvall O, Löfvenius MO (2002). Effect of shelterwood density on nocturnal near-ground temperature, frost injury risk and budburst date of Norway spruce. Forest Ecology and Management 168: 149-161. - doi: 10.1016/S0378-1127(01)00 754-X

Langvall O (2000). Interactions between nearground temperature and radiation, silvicultural treatments and frost damage to Norway spruce seedlings. PhD thesis, Swedish University of Agricultural Sciences, Almaro, Sweden, pp. 35.

Latif ZA, Blackburn GA (2010). The effects of gap size on some microclimate variables during late summer and autumn in a temperate broadleaved deciduous forest. International Journal of Biometeorology 54: 119-129. - doi: 10.1007/ s00484-009-0260-1

Lokvenc T, Dušek V, Jurásek A, Lokvenc T, Martincová J, Podrázský V, Vacek S, Haniš J, Minx A, Dušek M, Schwarz O (1992). Zalesnování Krkonoš. [Reforestation of the Krkonoše Mts]. Krkonošsky národní park, Vrchlabí. Forestry and Management Research Institute, Opočno, Czech Republic. [in Czech with English summary]

Menzies MI, Arnott JT (1992). Comparisons of different plant production methods for forest trees. In: Proceedings of the International Symposium on "Transplant Production Systems" (Kurata K, Kozai T eds). Yokohama (Japan) 2126 July 1992. Springer, the Netherlands, pp. 2144.

Otto HJ (1994). Waldökologie. Ulmer, Stuttgart, Germany.

Panferov O, Knyazikhin Y, Myneni RB, Szarzynski J, Engwald S, Schnitzler KG, Gravenhorst G (2001). The role of canopy structure in the spectral variation of transmission and absorption of solar radiation in vegetation canopies. Geoscience and Remote Sensing 39: 241-253. - doi: 10.1109/36.905232

Radler K, Oltchev A, Panferov O, Klinck U, Gravenhorst G (2010). Radiation and temperature responses to a small clear-cut in a spruce forest. The Open Geography Journal 3: 103-114. - doi: 10.2174/1874923201003010103

Ritter E, Dalsgaard L, Einhorn KS (2005). Light, temperature and soil moisture regimes following gap formation in a semi-natural beech-dominated forest in Denmark. Forest Ecology and Management 206 (1-3): 15-33. - doi: 10.1016/j.foreco.2004.08.011

Schmidt-Vogt H, Gurth P (1969). Eigenschaften von Forstpflanzen und Kulturerfolg. Allgemeine Forst- und Jagdzeitung 140: 132-142.

Slodičák M, Balcar V, Borůvka L, Fadrhonsová V, Jurásek A, Hadaš P, Kacálek D, Kantor P, Kulasová A, Kulhavý J, Leube F, Lomský B, Matějka K, Mauer O, Navrátil P, Nárovec V,
Novák J, Ostrovský J, Palátová E, Podrázský V, Rychnovská A, Říčař L, Skorupski M, Smejkal J, Souček J, Stoklasa M, Šach F, Šrámek V, Vacek S (2005). Lesnické hospodarení v Jizerskych horách, [Forestry management in the Jizerské hory Mts]. Lesy Ceské republiky, Hradec Králové; VÚLHM, Jílovište-Strnady, Czech Republic. [in Czech with English summary]

Slodičák M, Balcar V, Novák J, Šrámek V, Borůvka L, Derco D, Edgar D, Fadrhonsová V, Fiala P, Hadaš P, Hajnala M, Havránek F, Hellebrandová K, Humplík J, Hynek V, Jarský V, Jurásek A, Kacálek D, Kanák J, Kmínek A, Kobliha J, Kula E, Kulhavý J, Lachmanová Z, Lehner J, Lehnerová L, Lehečka J, Leugner J, Lomský B, Martincová J, Matějka K, Mauer O, Menšík L, Mutínský V, Nárovcová J, Nárovec V, Navrátil P, Novotný R, Nový L, Pěnička L, Pospíšil J, Pulkrab K, Skoblík J, Sloup M, Smějkal J, Sychrava J, Šišík L, Vortelová L, Vyslyšel K (2008). Lesnické hospodarení v Krušnych horách, [Forestry management in the Krušné hory Mts]. Lesy Ceské republiky. Hradec Králové. VÚLHM, Jíloviste-Strnady, Czech Republic. [in Czech with English summary]

Spittlehouse DL, Adams RS, Winkler RD (2004). Forest, edge, and opening microclimate at Sicamous Creek. Research Report, Ministry of Forests, British Columbia, Canada.

Tesar V (1982). Obnovní cíle a náhradní porosty vimisních oblastech, [Substitute tree species and their stands in air polluted areas]. In: "Obnova lesa v imisních oblastech". Prague, Czech Republic, pp. 75-80.[in Czech with English summary]

Uhlírová H, Kapitola P, Buriánek V, Fabiánek P, Pasuthová J, Balcar V, Šrámek V, Soukup F, Liška J, Šrůtka P, Cislerová E, Hradil K, Knížek M, Pešková V (2004). Poskození lesních drevin, Lesnická práce, Kostelec nad Cernymi Lesy, Czech Republic. [in Czech with English summary]

Vacek S, Balcar V (2000). Sudeten Mountains in the Czech Republic - growing conditions, regeneration and stabilization of mountain forests. In: Proceedings of the Internation Symposium "Multipurpose management of mountain forests: concepts, methods, techniques". Pralognan-la-Vanoise (France), 25-30 June 2000. European Observatory of Mountain Forest, IUFRO 2000, pp. 168-177.

Viewegh J, Kusbach A, Mikeska M (2003). Czech forest ecosystem classification. Journal of Forest Science 49: 74-82. [online] URL: http://www.agriculturejournals.cz/publicFiles/55710.pdf

Špulák O, Souček J (2010). Differences of air temperature in the interior and around the crown of young Norway spruce tree. Opera Corcontica 47: 225-238. [online] URL: http://opera.krnap. cz/_pdf/47/21Spulak\%20a\%20Soucek.pdf 